\title{
Teachers' perspectives on innovations: Implications for educational design
}

Citation for published version (APA):

Könings, K., Brand-Gruwel, S., \& Van Merriënboer, J. (2007). Teachers' perspectives on innovations: Implications for educational design. Teaching and Teacher Education, 23(6), 985-997.

https://doi.org/10.1016/j.tate.2006.06.004

DOI:

10.1016/j.tate.2006.06.004

Document status and date:

Published: 01/08/2007

Document Version:

Peer reviewed version

Please check the document version of this publication:

- A submitted manuscript is the version of the article upon submission and before peer-review. There can be important differences between the submitted version and the official published version of record. People interested in the research are advised to contact the author for the final version of the publication, or visit the DOI to the publisher's website.

- The final author version and the galley proof are versions of the publication after peer review.

- The final published version features the final layout of the paper including the volume, issue and page numbers.

Link to publication

\section{General rights}

Copyright and moral rights for the publications made accessible in the public portal are retained by the authors and/or other copyright owners and it is a condition of accessing publications that users recognise and abide by the legal requirements associated with these rights.

- Users may download and print one copy of any publication from the public portal for the purpose of private study or research.

- You may not further distribute the material or use it for any profit-making activity or commercial gain

- You may freely distribute the URL identifying the publication in the public portal.

If the publication is distributed under the terms of Article 25fa of the Dutch Copyright Act, indicated by the "Taverne" license above, please follow below link for the End User Agreement:

https://www.ou.nl/taverne-agreement

Take down policy

If you believe that this document breaches copyright please contact us at:

pure-support@ou.nl

providing details and we will investigate your claim.

Downloaded from https://research.ou.nl/ on date: 26 Apr. 2023 


\section{Running head: TEACHERS' PERSPECTIVE ON INNOVATIONS}

This is a pre-print of the article that was published as

Könings, K. D., Brand-Gruwel, S. \& van Merriënboer, J. J. G. (2007). Teachers' Perspective on Innovations: Implications for Educational Design. Teaching and Teacher Education, 23, 985-997.

http://www.elsevier.com/wps/find/journaldescription.cws_home/224/description\#description

(C) 2007 Elsevier.

Teachers' Perspectives on Innovations:

Implications for Educational Design

Karen D. Könings, Saskia Brand-Gruwel, and Jeroen J. G. van Merriënboer

Open University of the Netherlands

This research was supported by the Netherlands Organisation for Scientific Research (NWO) under project number 411-01-052.

Correspondence concerning this article should be addressed to Karen Könings,

Open University of the Netherlands, Educational Technology Expertise Center, PO Box 2960, 6401 DL Heerlen, The Netherlands. E-mail: karen.konings@,ou.nl 


\begin{abstract}
Educational designers often develop a 'powerful learning environment' that is subsequently implemented by teachers. Due to a lack of cooperation with teachers they may receive limited feedback on the quality of their design and the way it is implemented. This study focuses on teachers' perceptions of a Dutch innovative learning environment called the "Second Phase", as well as their desires and their dis/satisfaction with this environment. The results show that teachers are reserved about student autonomy and productive learning. Perceptions and desires are related to their individual approaches to teaching. The findings provide useful feedback for designers and a starting point to intensify their cooperation with teachers.
\end{abstract}


Teachers' Perspectives on Innovations:

Implications for Educational Design

During the last decade, many initiatives to modernise education and to optimise student learning have been taken in Dutch schools. Principles of cognitive psychology and constructivism are the basis for such innovations, which should eventually lead to 'powerful learning environments'. Such learning environments are aimed to reach the main goals of modern education: acquisition of high-quality knowledge, problem-solving skills, selfdirected learning skills, and transferability of knowledge and skills. In the literature several characteristics of a design of a powerful learning environment are described, like active knowledge construction, gradual transfer of responsibility, and complex and realistic learning tasks (see Könings, Brand-Gruwel \&, van Merriënboer, 2005, for an overview)

It is a general risk of large-scale innovations that educational designers develop a design or blueprint for a powerful learning environment that teachers subsequently do not or cannot fully implement in their teaching. This seems to have happened also in the innovation of Dutch secondary education (Veugelers, de Jong, \& Schellings, 2004). A nation-wide innovation in the higher grades of Dutch secondary education started in 1998, aiming to develop a powerful learning environment that should predominantly promote students' acquisition of self-directed learning skills. Teachers play a crucial role in the interpretation of an innovative design and its translation to educational practice. Therefore, the main goal of the current study is to find out how teachers think about the new powerful learning environment and which factors influence their perspective. Related aims are to investigate whether teachers in Dutch secondary education perceive the current learning environment as a powerful one, what they desire in this learning environment, and with which elements of the perceived learning environment they are dis/satisfied. 
Investigating teachers' perceptions of the learning environment gives insight in the extent to which the educational design has been successfully implemented. First of all, teachers are able to give information about successfully or unsuccessfully implemented aspects of the original design in the factual learning environment, for example, the degree to which productive learning and self-directed learning take place. This provides information about the current state of the implementation and its agreement with the original design. Secondly, teachers are an important source of feedback for educational designers, because not implementing particular aspects of the original design could also mean that it is not workable or feasible in practice. The design may not contain sufficient guidelines for good implementation or may simply not be suitable for realisation in educational practice.

When trying to implement a new educational design, teachers may experience failing preconditions at four levels: (1) the educational design itself, (2) the school, (3) the students, and (4) their own competencies. First, designers do not always take co-accountability for the translation of their ideas into practice (Staub, 2004). Too often, there is a lack of interaction between designers and teachers. Teachers are expected to autonomously transfer and apply educational systems and results of educational research. This, however, is an extremely complex task and may result in limited or inadequate implementation of the innovative design. Secondly, at the school level teachers work under particular conditions that may hamper the good implementation of an innovative design. For instance, smooth implementation may be hampered by a lack of time, large group sizes, inappropriate textbooks and media, and available classrooms that do not allow for individual work or work in small groups (Roelofs \& Terwel, 1999; Verloop \& Lowyck, 2003). Third, teachers' perceptions of student characteristics influence the choice and realisation of a learning environment. For example, if teachers perceive that less able students are overcharged in the learning environment, then they are likely to change or adapt it (Roelofs \& Terwel, 1999). 
Moreover, the perceived lack of passion in today's students may also negatively affect the implementation of new teaching practices (Simplicio, 2004). Fourth, teachers need to believe that they have the skills for implementing the innovation and thus have a positive expectancy of success with regard to the implementation in the specific context they are working in (Abrami, Poulsen, \& Chambers, 2004).

Apart from the aspects that teachers report as obstacles for innovating their educational practice, innovations may also suffer from teachers' unintended failure to incorporate new ways of teaching. Teachers' perceptions, desires and dissatisfaction (jointly called the "teacher's perspective") do not only reflect limiting preconditions from the outside world but also from the teachers' realm of thought. In the literature, four possible causes are described for teachers' resistance to innovations: (1) willingness to learn, (2) lack of consciousness of teaching behaviour, (3) incomplete reflection, and (4) dominant conceptions of teaching and learning.

First, teachers' willingness to learn is a crucial factor for implementing educational innovations. Teachers can be divided into three groups having different patterns of behaviour indicating their willingness to learn (van Eekelen, 2004). Teachers who do not see why there is a need to learn hold on to old teaching habits, do not have an open mind for others, are not very critical of their own role in education, and seldom reflect or ask themselves questions. Teachers who wonder how to learn want to improve their teaching practices but do not know how to accomplish this. They are mostly critical of their own role and are a bit more open to others. Teachers who are eager to learn want to improve their performances and undertake action in order to learn. They are alert to classroom processes, have an open mind for others, and are critical towards their own role.

Second, a lack of consciousness of own teaching behaviour can make traditional teaching practices highly persistent. Only part of teachers' teaching behaviour is conscious 
and reflective (Tigchelaar \& Korthagen, 2004). Routines and spontaneous, immediate reactions determine much of a teacher's classroom behaviour. Teachers have to react very quickly to things happening in the classroom when educating about 25 to 30 students. Because these unconscious behaviours and routines are based on earlier and often more traditional educational experiences, they may interfere with the implementation of educational innovations that expect new teaching behaviours from teachers.

Third, teachers reflect only on a part of the whole educational process. They mainly reflect on the desired manifestation of their teaching, which means that they focus on the educational methods and strategies they plan to use in their lessons (Ponte, Ax, Beijaard, \& Wubbels, 2004). They rarely reflect on the current educational reality and the effects of their teaching behaviours (ibid). This one-sided way of reflecting on education is likely to hamper the implementation of educational innovations.

Finally, teachers differ in their conceptions of teaching and learning. It has been shown that conceptions influence perceptions. Conceptions can be seen as lenses through which people perceive and interpret the world (Pratt, 1992). Conceptions of teaching and learning can be placed on a continuum between a teacher-centered/content-oriented pole and a student-centered/learning-oriented pole (Kember, 1997). Conceptions on the latter side of the continuum are most compatible with educational innovations based on constructivism and ideas behind powerful learning environments. Teachers' conceptions of teaching and learning are influencing teachers' approaches to teaching (Trigwell, Prosser, \& Waterhouse, 1999) and their way of acting and reacting in the learning environment (Pratt, 1992). This implies that conceptions may influence the way teachers implement an educational design through their approaches to teaching, which can be seen as an operationalisation of their conceptions. This influence could be reflected in teachers' perceptions of the learning environment, desires, and dissatisfaction with the current learning environment. 
Practical experiences at the level of design, school, students, and teachers' own competencies and self-efficacy, as well as teachers' individual characteristics, are reflected in teachers' perceptions of the learning environment, the way they would like the learning environment to be (i.e., desires), and their dissatisfaction with elements of the current learning environment. So, teachers are able to give important feedback to those who designed the educational innovation (see also Könings, Brand-Gruwel, \& van Merriënboer, 2005; West \& Staub, 2003). The perspective of teachers provides information about the practical side of the design, which is in fact indispensible for designers.

Only informing designers about teachers' experiences with the designed learning environment, would be the weakest form of cooperation between designers and teachers (i.e., implementors) (Kensing \& Blomberg, 1998). A stronger form of cooperation is participatory design, aiming at an active participation of users in the design process and in decisions that will affect them (Kensing \& Blomberg, 1998; Markin, 1997). Participatory design is already used in business (Mumford, 1997) and in developing technology (Mankin, 1997), and more specific in the design process of computer applications (Bodker, 1996). The participatory design process constitutes analysis of needs and possibilities, generation of visions for change, project management and planning for implementation (Kensing, Simonsen, \& Bodker, (1998). Some important benefits of participatory design are: (1) an improved quality and usability of the design, (2) easier acceptance of innovations by its users, (3) a better understanding of innovations by the users resulting in a more effective implementation, and (4) less investments in innovations that users do not want or cannot use in practice (Damodaran, 1996).

For good functioning of participatory design it is important to be well-informed on teachers' perspective in implementing a new educational design, and how this is related to teachers' individual characteristics. The current study answers the question of how teachers 
perceive, desire, and appreciate an innovative learning environment, and examines the relation between teachers' perspectives and their approaches to teaching. Additionally, possible relations with the amount of teaching experience, sex, and courses teachers are teaching will be explored. Shortly, the current study answers the following research questions:

1. How do teachers perceive the current innovative learning environment (in Dutch secondary education), what do they desire in a learning environment and with which elements of the perceived learning environment are they dissatisfied?

2. How are perceptions, desires, and dis/satisfaction related to approaches to teaching, amount of teaching experience, sex, and courses teachers are teaching?

\section{Method}

\section{Participants}

The sample consisted of 142 teachers of five schools for secondary education in the south of the Netherlands. They were all teaching $10^{\text {th }}$ grade students (about 16 years old) in senior general secondary education and/or pre-university education and were expected to implement the innovative learning environment, called "Second Phase". The teachers' mean age was 44.40 years $(S D=9.77)$, having on average 18.40 years $(S D=10.21)$ of teaching experience. The sample consisted of 47 female teachers $(33.8 \%)$ and 92 male teachers $(66.2$ \%) Three teachers did not indicate their sex. The participants were teaching different kinds of courses (see Table 1). Four teachers did not specify which courses they were teaching.

\section{Materials}

The learning environment. The context of this study is a nation-wide innovation in Dutch secondary education, called Second Phase (Ministerie van OCW, 2005; Stuurgroep Profiel Tweede Fase Voortgezet Onderwijs, 1995; Veugelers, de Jong, \& Schellings, 2004). This learning environment requires students to acquire skills and knowledge in an independent way, better preparing them for higher professional education and university. 
Students learn in a self-directed way, with opportunities for collaborative learning. In this learning environment there is more room to account for individual differences than in the traditional class situation. The teacher has to be sensitive to student's indiviual progress and problems. The learning process is not only directed to knowledge acquisition, but also to the selection and processing of the vast amounts of information available today. In this learning environment the teacher serves more as a coach and less as an instructor. This creates more possibilities for contact between students and the teacher. Furthermore, learning contents are actualised and broadened. Building a broad general knowledge base is an important educational goal of the Second Phase. The integration of different subject matter domains is emphasised. Courses are clustered in profiles or "themes" of closely interconnected subject matters. According to the educational designers of the learning environment, this enables more integration between subjects and leads to a better preparation for higher professional education and university. In addition to more integration between subjects, the coherence between knowledge and skills is emphasised and the application of acuired knowledge is stressed.

Background Questionnaire. This short questionnaire is aimed to get insight in teachers' individual background characteristics. It contained four open questions about the teacher's age, the number of years of teaching experience, sex, and the courses taught.

Inventory of Perceived Study Environment Extended-Teacher (IPSEE-T). The aim of the IPSEE-T is to measure teacher's perceptions of a particular learning environment and their desires with regard to the design of a learning environment. These measures together give insight in teachers' dis/satisfaction with the learning environment, by looking at the discrepancies between perceptions and desires.

The IPSEE-T consists of 67 items. Thirty-one of these items originate from the Inventory of Perceived Study Environment (IPSE; Wierstra, Kanselaar, van der Linden, \& 
Lodewijks, 1999), translated into Dutch by the Expertise Centre Active Learning of Maastricht University (Picarelli, Bouhuijs, \& Vermunt, 2006). To measure the characteristics of powerful learning environments more completely, as described by Könings, Brand-Gruwel, and Van Merriënboer (2005), another 36 items were constructed. The original version of the IPSE is intended for completion by students. For the current study the IPSEE-T has been adapted for administration to teachers.

The items of the IPSEE-T cover eight scales (see Table 2) that are considered as central characteristics of powerful learning environments. The first scale is fascinating contents and contains items about the extent to which the learning contents are interesting, challenging, and personally relevant for students. The second scale is productive learning. The less emphasis on sole reproduction of learning contents, the higher the score on this scale. Thus, scores on this scale are reversed in order to express productive learning. The third scale is integration and includes items about the integration of newly acquired knowledge with prior knowledge, the integration of different knowledge domains, and the integration of knowledge and skills. The fourth scale is student autonomy and intends to measure the attention to student's self-steering with regard to the content of learning, the way of learning, and time planning. The fifth scale is interaction, which incorporates both collaboration with peers and interaction with the teacher. The sixth scale is differentiation, which inquires after opportunities for students to choose and make different tasks, solve problems in different ways, and use different learning materials. The seventh scale is clarity of goals and includes items about the clarity of instructional goals and task demands. The eighth and last scale is personalisation, which inquires after the availability of tailored teacher support.

Each of the items of the IPSEE-T contains a statement about one of the characteristics of a learning environment and two questions, as illustrated in Figure 1. The questions are rated on a six-point scale, ranging from totally disagree to totally agree. Scores on question A 
measure the perceptions of the teacher's learning environment. Scores on question B indicate what the desired learning environment of the teacher would look like. The discrepancy (i.e., absolute difference) between the scores on question A and question B is defined as the measure of dissatisfaction with the particular learning environment. Increasing discrepancies between perceptions and desires indicate increasing dissatisfaction. Small discrepancies between perceptions and desires indicate low dissatisfaction. It should be noted that low dissatisfaction can also be seen as high satisfaction, but only the term dissatisfaction is used to interpret the results in an univocal way.

Internal consistency is computed for all eight scales, separately for the perception items and the desire items (see Table 2). All Cronbach's alpha coefficients were above .70, except for two coefficients that were between .60 and .70 . Thus, the internal consistencies of all scales were acceptable.

Approaches to Teaching Inventory (ATI). The aim of the ATI (Prosser \& Trigwell, $1997)$ is to measure teaching approaches. The questionnaire contains two scales: Informationtransmission/teacher-focused (ITTF) and conceptual-change/student-focused (CCSF). These scales represent the extreme teaching approaches on a scientifically well known continuum of approaches between a teacher-centered/content-oriented pole and a student-centered/learningoriented pole (see Kember, 1997; Prosser \& Trigwell, 1993). The ATI has been translated in Dutch and now contains 11 items. The scale ITTF consists of 5 items $(\alpha=.66)$ and the scale CCSF consists of 6 items $(\alpha=.72)$. All items are rated on a six-point scale, ranging from totally disagree to totally agree.

\section{Procedure}

The participants received an invitation to take part in the study accompanied by the questionnaires and a description of the goal of the study. The first page of each questionnaire contained a description of the aim and the contents of the questionnaire and instructions for 
scoring the items. Participant first had to fill out the background questionnaire, followed by the IPSEE-T, and the ATI. They could fill out the questionnaires at any moment and place they wanted. In total 142 of the 246 teachers returned the questionnaires (i.e., $57.7 \%$ ).

\section{Data Analysis}

For computing mean scores for each scale of the IPSEE-T, maximally $25 \%$ of missing values is accepted. So, if at least $75 \%$ of the items at scale level were filled out, these items were used to compute the mean score. Looking at the mean scores, it showed that on each scale for at least $85 \%$ of the teachers a mean score could be calculated, except for the scale integration (11 items). For this scale a mean score was calculated for only $63 \%$ of teachers. The missing-value procedure was adapted for the integration-scale, because it appeared that three items were not applicable to all teachers. These three items referred to integration of theory lessons and practicals. Not all courses included practicals, with the consequence that part of the teachers could not answers these particular items. Therefore, the procedure for this scale was adapted as follows: If $75 \%$ of the eight remaining items of the scale were filled out, then the mean of all answered items (including the three particular items) was computed.

One-sample $t$-tests were used to investigate whether perception scores and desire scores differ from the neutral score of 3.5. Paired-samples $t$-tests were used in order to test whether discrepancies between perceptions and desires, indicating dissatisfaction, were significant. Multiple regression analyses were used to investigate relations between perceptions on the one hand, and teaching approaches, years of teaching experience, sex, and courses taught on the other hand. In the first step of the regression analysis dummies for the school variable were entered in the regression model to correct for possible school effects. In the second step, the independent variables were added using a stepwise forward procedure. The same analyses were used to investigate relations of desires and dissatisfaction with 
teachers' individual characteristics. Only independent variables explaining at least $10 \%$ of the variance are reported in the text.

\section{Results}

For answering the first research question teachers' perception scores will be reported, as well as the desire scores and the dissatisfaction scores. In relation to the second research question, statistics of the Approaches to Teaching Inventory will be described. Besides, the results of multiple regression analyses will be reported, showing relations (1) between teachers' perception scores and their individual characteristics, (2) between desire scores and individual characteristics, and (3) between dissatisfaction scores and individual characteristics.

\section{Perceptions, Desires, and Dissatisfaction}

The eight mean scores of the different scales of the IPSEE-T (see Figure 2) showed that teachers perceived the learning environment predominantly as a powerful learning environment. One-sample $t$-tests showed that on six of the eight scales the perception scores were significantly higher than the neutral score of 3.5 ( $p<.01$ for all tests). Teachers perceived fascinating contents, emphasis on productive learning, integration in the learning contents, interaction during the learning process, clarity of goals, and personalisation as significantly higher than neutral. On two scales the perception scores were significantly below 3.5 ( $p<.01$ for both tests). Teachers perceived differentiation and student autonomy significantly lower than neutral, although they were still scored higher than 3.0 (i.e., above 'a bit disagree').

The desire scores of the IPSEE-T give insight in the ideal learning environment of the teachers. One-sample $t$-tests showed that on six of the eight scales the desire scores were significantly above 3.5 ( $p<.01$ for all tests), which means that teachers clearly desired most of the characteristics of the learning environment, as measured by the IPSEE-T. Only the 
desires of productive learning and differentiation did not significantly differ from the neutral score.

The discrepancy between perception scores and desire scores is interpreted as a measure of the dissatisfaction with the perceived learning environment. By looking at the difference between the perception bar and the desire bar in Figure 1, the dissatisfaction can be deduced. The more both bars differ, the higher the dissatisfaction (e.g., see fascinating contents). The more both bars match, the lower the dissatisfaction (e.g., see differentiation). Although the size of the discrepancies differs among scales, paired $t$-tests showed that for all scales the perception scores differed significantly from the desire scores $(p<.01)$. For seven of the eight scales the perception scores were lower than the desire scores. Productive learning was the only scale that showed higher perception scores than desire scores $(p<.01)$. Surprisingly, teachers preferred more reproductive learning in the learning environment than they actually experienced.

Because all discrepancies between perceptions and desires were significant, it is valuable to compute our measure of dissatisfaction with the perceived learning environment and to use it in further analyses. The means and standard deviations of the dissatisfaction scores are presented in Table 3, together with the means and standard deviations of the perception scores and the desire scores. It can be seen from Table 3 that teachers were especially dissatisfied with the extent to which the learning contents are fascinating for students, the room for interaction during the lessons, the integration in the learning contents, and the possibility for student autonomy.

\section{Approaches to Teaching}

Teachers reported both the ITTF approach $(M=4.22 ; S D=.70)$ and the CCSF approach to teaching $(M=3.91 ; S D=.73)$. A one-sample $t$-test on the scores of the ATI showed that on both scales the means were significantly higher than the neutral score of 3.5 
$(p<.01)$. A paired $t$-test showed that the scores on the ITTF scale were significantly higher than the scores on the CCSF scale, $t(133)=3.57, p<.01$. So, teachers considered teaching primarily as information transmission in a teacher focused educational context.

\section{Perception Scores and Teachers' Individual Characteristics}

Table 4 presents the results of the multiple regression analyses of teachers' individual characteristics on the perception scores of the scales of the IPSEE-T. The independent variables included in the analyses are: Approaches to teaching, sex, years of teaching experience, and courses taught. The results in Table 4 are corrected for possible school effects, by including the variable school in all models. The analyses showed that part of the variance of the perception scores on different scales was explained by the teaching approach. The more teachers reported a CCSF approach to teaching, the higher the perception scores of integration. For the scales student autonomy and interaction, the CCSF approach also contributed to high perception scores. The perception scores of differentiation were negatively related to the ITTF approach. The more teachers reported this teaching approach, the lower their perception scores of differentiation. The perception of clarity of goals was related to the course teachers were teaching: Teachers teaching language courses perceived more clarity of goals than others. Sex hardly related to perception scores, and years of teaching experience did not relate to perception scores on any scale.

In short, the regression models reported in Table 4 show that approaches to teaching are often related to perception scores. Teachers reporting a CCSF approach perceive a more powerful learning environment on half of the scales of the IPSEE-T. Teachers reporting an ITTF approach perceive a less powerful learning environment on half of the scales.

\section{Desire Scores and Teachers' Individual Characteristics}

The results of the multiple regression analyses of teachers' individual characteristics on desire scores of the IPSEE-T (see Table 5) showed that the more teachers reported a CCSF 
approach, the higher their desire scores on integration, student autonomy, and interaction. On the scale differentiation the ITTF approach contributed to low desire scores. Overall, the results in Table 5 show that approaches to teaching explain part of the variance of the desire scores on seven of the eight scales. The CCSF approach was related to high desires. The ITTF approach is two times related to low desires and two times to high desires. The courses the teachers were teaching related to their desire scores on three scales. The number of years of teaching experience and sex show no relation with desire scores.

\section{Dissatisfaction Scores and Teachers' Individual Characteristics}

There was only one significant regression weight in all multiple regression analyses of teachers' individual characteristics on dissatisfaction scores. Teachers teaching creative courses were more dissatisfied about the clarity of goals $\left(R^{2}=.61 ; \Delta R^{2}=.04 ; B=.33 ; S E B\right.$ $=.11 ; \beta=.20)$ than teachers teaching other courses. The lack of significant findings in the multiple regression analyses of the dissatisfaction scores indicate that teachers, independent from their individual characteristics, are all equally dissatisfied with the perceived learning environment. There was no influence of teaching approaches on dissatisfaction. There were also no relations between dissatisfaction scores and sex, years of teaching experience, and courses taught.

\section{Conclusions and Discussion}

The current study gives insight in teachers' perceptions, their desires, and their dissatisfaction with the "Second Phase" in Dutch secondary education, as well as the relation of these variables with teachers' individual characteristics.

The first research question focused on the teacher's perspective of the current innovation in Dutch secondary education. The results show that teachers perceive a predominantly powerful learning environment, except for student autonomy and differentiation. It is particularly remarkable that student autonomy is not perceived as 
pronouncedly present in the learning environment, because this is one of the elementary characteristics of its underlying educational design.

The desires show that teachers positively value almost all measured elements of a powerful learning environment, including student autonomy. Teachers are neutral about the desirability of differentation and productive learning. In the light of educational trends such as education-on-demand and adaptive teaching it is striking that differentiation is not an important issue for teachers: they do not recognize it in their own environment and they do not value it very highly. This might be explained by the fact that students are already grouped together in two levels (at school level), based on their capacities: Senior general secondary education and pre-university education. However, at class level one might still expect that variation between students in capabilities and interests would give further reason for differentiation.

Except for productive learning, the results of dissatisfaction scores show that teachers desire a more powerful learning environment than they perceive at the moment. Teachers are especially dissatisfied with the lack of challenging and fascinating contents, the low amount of interaction during the learning process, the inadequate integration of subject matter, and the amount of student autonomy. Teachers are also dissatisfied with respect to productive learning, but the desire scores are lower than the perception score. Apparently, teachers prefer less emphasis on productive learning than they currently experience in the learning environment, formulated otherwise, they prefer more reproduction of knowledge than they perceive. This is clearly not in line with constructivist ideas, which stress the importance of the construction of knowledge by learners themselves (Jonassen, 1991).

The second research question focused on the relations between teachers' perceptions, desires, and dissatisfaction on the one hand, and their approaches to teaching, amount of teaching experience, sex, and courses taught on the other hand. Results show that teachers' 
perceptions are related to their approaches to teaching. Teachers reporting the CCSF approach perceive a more powerful learning environment, while teachers reporting the ITTF approach perceive a less powerful learning environment. Teachers' perceptions are sometimes related to the courses taught, hardly related to sex, and never related to years of teaching experience.

A possible explanation for the found relation between perceptions and approaches to teaching (i.e. operationalised conceptions) is that the conceptions influenced the perception process. Conceptions operate as lenses through which one looks (Pratt, 1992). Another plausible explanation is that teachers perceive different educational practices. Teachers all have their own way of teaching and usually only perceive their own lessons. Thus, the object of the perception may have differed, which itself was out of the scope of this study. If teachers teach according to their own approach to teaching, they are likely to perceive a learning environment that is in line with their approaches to teaching. However, this means that they have the freedom to do so because the educational design is not highly prescriptive.

Teachers reporting a CCSF approach desire a more powerful learning environment. The direction of the relation between desires and the ITTF approach is equivocal. The stronger the ITTF approach, the lower the desires for productive learning and differentiation, and the higher the desires for clarity of goals and personalisation. Productive learning and differentiation are less desirable elements of the learning environment if the teacher considers information transmission as the goal of education, doing so in a teacher-focused manner. The clarity of goals and personalisation as characteristics of powerful learning environments, however, can also fit well in the more traditional ITTF approach to teaching.

Dissatisfaction is hardly related to teachers' individual characteristics. There is a single relation with the courses taught, but no relation with sex and years of teaching experience. Dissatisfaction is totally independent from approaches to teaching: Teachers with a CCSF approach and an ITTF approach are equally dissatisfied with the learning 
environment. This is remarkable, because the design characteristics of the "Second Phase" fit better to the CCSF approach than to the ITTF approach. A likely conclusion is that all teachers can constitute their educational practices according to their own approaches to teaching to the same extent. If this is true, the educational design of the Dutch innovation in secondary education is only implemented as far as it is in agreement with teachers' approaches to teaching.

Remarkably, there is a lack of a relation between years of teaching experience and the teachers' perspective. It indicates that teachers who just graduated and enter practice (mostly young teachers) do not perceive a more powerful learning environment, or are more dissatisfied with the perceived learning environment, than more experienced teachers. This means that young teachers are not more inclined to innovate than their experienced colleagues, which could be explained by quick socialisation and adaptation to the current school practices (Pugh \& Zhao, 2003).

What causes can be identified for the hampering implementation of the design of the learning environment? The study showed several aspects that are in contrast with the original design. Teachers perceive the current learning environment as a powerful one, with the exception of differentiation and student autonomy. The autonomy of students is not seen as highly desirable and a productive way of learning is even less desired than perceived. Furthermore, teachers seem to design their education according to their own approaches to teaching. What may cause this incomplete implementation of the learning environments? From the comments teachers wrote at the end of the questionnaire, it became clear that they experience problems with the feasibility of the design. The following comments may explain the conservative attitude with respect to student autonomy. Teachers stated that the connection between students' prior education and the Second Phase is missing and students are not prepared to learn in a self-directed way. Teachers also remarked that high-ability 
students function well in the innovative learning environment, but students with less learning capabilities tend to get lost. Additionally, they mentioned that it costs a lot of discipline and skills for young students to work seriously in an environment that offers much freedom. Part of the students has motivational problems. "Students do not have a clear goal yet." Teachers' preferences for more reproductive learning are better understandable in the context of the following remarks. Teachers commented that students are overloaded with too many courses in the new learning environment and that (too) limited lesson time can be spend on different subjects. Additionally, skills are stressed in the new learning environment and students have to write many papers and conduct many projects. According to the teachers, these characteristics of the design of the learning environment may lead to superficiality and little deepening of the subject matter. Additionally, a few teachers reported difficulties with the innovative learning environment, because they did not feel well prepared to implement the Second Phase. So, teachers mention failing preconditions at the level of the educational design, the school, the students and their own competenties.

Next to these reflective information about the current implementation of the learning environment, this study shows influences of teachers' conceptions on the implementation. From the literature it is known that it is difficult to change conceptions and beliefs (e.g., Chinn \& Brewer, 1993). Teachers have built their conceptions and beliefs about teaching from their own experiences as students in primary, secondary, and tertiary education and from their - sometimes lengthy - teaching experiences in the period before starting the innovation. Conceptions are heavily resistant to change. And, according to cognitive dissonance theory (Festinger, 1957), people prefer congruence between cognitions (i.e., beliefs) and behaviour. If a limited prescriptive educational design places few constraints on teaching behaviours, it is easier to stick to existing behaviours than to change the cognitions. The results of the current study may indicate the design of the learning environment is not well-defined enough. 
A limitation of the current study is that the relation between conceptions (operationalised as approaches to teaching) and perceptions cannot be separated from the relation between approaches to teaching and the way in which teachers constitute the learning environment. In order to get more grasp on this, one has to focus, additionally, on the "objective" learning environment, for example with video observations in the classroom. This is an important line for future research. Another limitation of the study is that teachers may have answered the questionnaire in a socially desirable manner. However, if this effect played a role at all, it seems to be small, because the responses on the different scales of the IPSEE-T clearly differentiated and many answers were not in agreement with the design of the innovative learning environment or today's educational insights.

A practical implication of our study is that an innovative educational design should offer teachers much guidance for how to implement it in practice, because our results indicate that teachers otherwise tend to implement the innovation in accordance with their own approaches to teaching - which are not always in line with the intended design. Therefore, the design needs to be explicit about the teaching behaviours expected from the teachers. However, it is highly necessary that such a design is workable and feasable for teachers. Therfore, a second practical implication is that cooperation between educational designers and teachers should be promoted and become common practice. Because teachers experience problems in the feasibility of the design, they themselves adapt the design to a practical form. These feasibility problems provide important feedback for designers and a starting point for cooperating with teachers more closely in order to develop a more workable design. The principles of participatory design can give practical guidance for this cooperation. By more intensive cooperation between designers and teachers, the scope of the innovative design can be enhanced because it makes it easier for teachers to teach according to the design rather 
than according to their own approaches to teaching. This is especially relevant for reaching "traditional" teachers when implementing innovations.

To conclude, this study showed the importance of exploring the perspective of teachers who are involved in an educational innovation. It showed that the implementation of the innovative learning environment only partly succeeded and that more cooperation between educational designers and teachers is needed to create more congruence between the educational design and the factual learning environment in the classroom. Such a cooperatively developed design will contribute more to promoting good educational practices than a design developed without acknowledgment of the teacher's perspective. Furthermore, such a design will be more workable for teachers and, eventually, better able to assist teachers in innovating their education. Making the design more specific and concrete could help more traditional teachers to succesfully implement an innovation. 


\section{References}

Abrami, P. C., Poulson, C., \& Chambers, B. (2004). Teacher motivation to implement an educational innovation: Factors differentiating users and non-users of cooperative learning. Educational Psychology, 24(2), 201-216.

Bodker, S. (1996). Creating conditions for participation: conflicts and resources in systems development. Human-computer interaction, 11, 215-236.

Chinn, C. A., \& Brewer, W. F. (1993). The role of anomalous data in knowledge acquisition: A theoretical framework and implications for science instruction. Review of Educational Research, 63(1), 1-49.

Damodaran, L. (1996). User involvement in the systems design process - a practical guide for users. Behaviour \& Information Technology, 15(6), 363-377.

Festinger, L. (1957). A theory of cognitive dissonance. Stanford, CA: Stanford University Press.

Jonassen, D. H. (1991). Objectivism versus constructivism: Do we need a new philosophical paradigm? Educational Technology, Research \& Development, 39(3), 5-14.

Kember, D. (1997). A reconceptualisation of the research into research into university academics' conceptions of teaching. Learning and Instruction, 7(3), 255-275.

Kensing, F., \& Blomberg, J. (1998). Participatory design: issues and concerns. Computer Supported Cooperative Work, 7, 167-185.

Kensing, F., Simonsen, J., \& Bodker, K. (1998). MUST: a method for participatory design. Human-computer interaction, 13, 167-198.

Könings, K. D., Brand-Gruwel, S., \& van Merriënboer, J. J. G. (2005). Towards more powerful learning environments through combining the perspectives of designers, teachers and students. British Journal of Educational Psychology, 75(4), 645-660. 
Mankin, D., Cohen, S. G., \& Bikson, T. K. (1997). Teams and technology: tensions in participatory design. Organizational dynamics, 26(1), 63-74.

Ministerie van Onderwijs, Cultuur en Wetenschap (n.d.) Dossier Tweede Fase [Dossier Second Phase]. Retrieved August 1, 2005, from http://www.minocw.nl/tweedefase/factsheet.html

Mumford, E. (1997). The reality of participative systems design: contributing to stability in a rocking boat. Information Systems Journal, 7, 309-322.

Picarelli, A., Bouhuijs, P. A. J., \& Vermunt, J. D. (2006). Leerstijl en leeromgeving in het Voortgezet Onderwijs: Nederland en Vlaanderen vergeleken [Learning style and learning environment in secondary education: the Netherlands and Flanders compared]. Pedagogische Studiën, 83(2), 139-155.

Ponte, P., Ax, J., Beijaard, D., \& Wubbels, T. (2004). Teachers' development of professional knowledge through action research and the facilitation of this by teacher educators. Teaching and Teacher Education, 20, 571-588.

Pratt, D. D. (1992). Conceptions of teaching. Adult Education Quaterly, 42(4), 203-220.

Prosser, M., \& Trigwell, K. (1993). Development of an approaches to teaching questionnaire. Research and Development in Higher Education, 15, 468-473.

Prosser, M., \& Trigwell, K. (1997). Relations between perceptions of the teaching environment and approaches to teaching. British Journal of Educational Psychology, 67, $25-35$.

Pugh, K. J., \& Zhao, Y. (2003). Stories of teacher alienation: A look at the unintended consequences of efforts to empower teachers. Teaching and Teacher Education, 19, 187201. 
Roelofs, E. C., \& Terwel, J. (1999). Constructivism and authentic pedagogy: State of the art and recent developments in the Dutch national curriculum in secondary education. Journal of Curriculum Studies, 31, 201-227.

Simplicio, J. S. C. (2004). Today's teachers struggle to educatie a generation of students unlike any that has ever been seen before. Journal of Instructional Psychology, 31(1), 7175.

Staub, F. C. (2004). Transforming educational theory into usable knowledge: A case of coconstructing tools for lesson design and reflection. In B. Ralle \& I. Eilks (Eds.), Quality in practice-oriented research in science education (pp. 41-52). Aachen, Germany: Shaker.

Stuurgroep Profiel Tweede Fase Voortgezet Onderwijs (1995). Verschil moet er zijn [There should be a difference]. Den Haag, The Netherlands: Stuurgroep Profiel Tweede Fase Voortgezet Onderwijs.

Tigchelaar, A., \& Korthagen, F. (2004). Deepening the exchange of student teaching experiences: implications for the pedagogy of teacher education of recent insights into teacher behaviour. Teaching and Teacher Education, 20, 665-679.

Trigwell, K., Prosser, M., \& Waterhouse, F. (1999). Relations between teachers' approaches to teaching and students' approaches to learning. Higher Education, 37, 57-70.

Van Eekelen, I. M. (2005). Teachers' will and way to learn: Studies on how teachers learn and their willingness to do so. Unpublished doctoral dissertation, Maastricht University, The Netherlands.

Verloop, N., \& Lowyck, J. (Eds.). (2003). Onderwijskunde: een kennisbasis voor professionals [Educational theory: a knowledge base for professionals]. Groningen, The Netherlands: Wolters-Noordhoff. 
Veugelers, W., De Jong, U., \& Schellings, G. (2004). Studie naar het onderzoek van de tweede fase havo/vwo [Metastudy of research of the second phase in senior general secondary education / pre-university education]. Amsterdam, The Netherlands: Instituut voor de Lerarenopleiding.

West, L., \& Staub, F. C. (2003). Content-focused coaching. Portsmouth, NH: Heinemann.

Wierstra, R. F. A., Kanselaar, G., Linden van der, J. L., \& Lodewijks, H. G. L. C. (1999).

Learning environment perceptions of European university students. Learning Environments Research, 2, 79-98. 
Table 1

Frequencies of the Different Kind of Courses the Participants were Teaching

\begin{tabular}{lcc}
\hline & Absolute frequency & Percentage \\
\hline Teaching languages courses $^{1}$ & 52 & $37.7 \%$ \\
Teaching science courses $^{2}$ & 36 & $26.1 \%$ \\
Teaching general education courses $^{3}$ & 31 & $22.5 \%$ \\
Teaching creative courses $^{4}$ & 12 & $8.5 \%$ \\
Teaching a combination of courses $^{5}$ & 7 & $4.9 \%$ \\
\hline
\end{tabular}

${ }^{1}$ Dutch, German, English, French, classical languages

${ }^{2}$ General science, biology, chemistry, physics, mathematics, computer technology

${ }^{3}$ History, geography, economics, social studies, philosophy of life

${ }^{4}$ Cultural and artistic appreciation, drawing, handicrafts, music, physical education

${ }^{5}$ Teaching courses in more than one of the above categories 
Table 2

Internal Consistencies of the Scales of the IPSEE-T

\begin{tabular}{lccc}
\hline & & \multicolumn{2}{c}{ Cronbach's alpha coefficient } \\
\cline { 3 - 4 } & Number & Perception & Desire \\
& & & \\
& of items & & \\
\hline Fascinating contents & 9 & .78 & .80 \\
Productive learning & 5 & .74 & .80 \\
Integration & 11 & .77 & .76 \\
Student autonomy & 15 & .87 & .87 \\
Interaction & 11 & .75 & .64 \\
Differentiation & 6 & .79 & .72 \\
Clarity of goals & 4 & .77 & .70 \\
Personalisation & 6 & .68 & \\
\hline
\end{tabular}


Table 3

Means and Standard Deviations of Dissatisfaction Scores (Ordered from High to Low), Perception Scores, and Desire Scores

\begin{tabular}{lcccccc}
\hline & \multicolumn{2}{c}{ Dissatisfaction } & \multicolumn{2}{c}{ Perceptions } & \multicolumn{2}{c}{ Desires } \\
\hline & $M$ & $S D$ & $M$ & $S D$ & $M$ & $S D$ \\
\hline Fascinating contents & 1.14 & .62 & 4.06 & .64 & 5.20 & .46 \\
Interaction & .79 & .54 & 4.05 & .57 & 4.84 & .52 \\
Integration & .64 & .46 & 4.43 & .60 & 5.07 & .49 \\
Student autonomy & .52 & .54 & 3.26 & .69 & 3.79 & .76 \\
Personalisation & .24 & .36 & 5.12 & .48 & 5.37 & .45 \\
Differentiation & .21 & .58 & 3.23 & .84 & 3.44 & .87 \\
Clarity of goals & .19 & .36 & 5.25 & .55 & 5.45 & .53 \\
Productive learning $^{\mathrm{a}}$ & .12 & .48 & 3.78 & .92 & 3.66 & 1.07 \\
\hline
\end{tabular}

${ }^{\mathrm{a}}$ For this scale perception scores were higher than desire scores. 
Table 4

Significant Regression Weights $(p<.05)$ of Variables Predicting Perceptions

\begin{tabular}{lcclccc}
\hline Dependent variable & $R^{2}$ & $\Delta R^{2}$ & Independent variable $(s)$ & $B$ & SE B & $\beta$ \\
\hline Fascinating contents & .17 & .08 & CCSF approach & .25 & .08 & .29 \\
Productive learning & .21 & .06 & ITTF approach & -.34 & .12 & -.26 \\
& & .04 & Creative courses & .73 & .30 & .21 \\
Integration & .26 & .18 & CCSF approach & .36 & .07 & .44 \\
Student autonomy & .27 & .12 & CCSF approach & .33 & .08 & .35 \\
& & .06 & ITTF approach & -.24 & .08 & -.26 \\
Interaction & .29 & .15 & CCSF approach & .31 & .07 & .38 \\
& & .06 & ITTF approach & -.21 & .07 & -.25 \\
Differentiation & .19 & .15 & ITTF approach & -.45 & .10 & -.39 \\
Clarity of goals & .13 & .11 & Language courses & .37 & .10 & .33 \\
Personalisation & .16 & .04 & Sex & -.20 & .09 & -.20 \\
\hline
\end{tabular}

Note. All multiple regression models are corrected for school effects. $R^{2}$ is the total amount of explained variance of the model, including school effects. $\Delta R^{2}$ is the change in $R^{2}$ after adding the particular independent variable in the model. 
Table 5

Significant Regression Weights $(p<.05)$ of Variables Predicting Desires

\begin{tabular}{lcclccc}
\hline Dependent variable & $R^{2}$ & $\Delta R^{2}$ & Independent variable $(s)$ & $B$ & $S E B$ & $\beta$ \\
\hline Fascinating contents & .01 & & & & & \\
Productive learning & .17 & .05 & ITTF approach & -.33 & .14 & -.22 \\
& & .03 & Language courses & -.42 & .21 & -.19 \\
Integration & .19 & .17 & CCSF approach & .28 & .06 & .43 \\
Student autonomy & .18 & .14 & CCSF approach & .40 & .10 & .38 \\
Interaction & .20 & .17 & CCSF approach & .31 & .07 & .42 \\
Differentiation & .16 & .15 & ITTF approach & -.46 & .11 & -.40 \\
Clarity of goals & .13 & .08 & Language courses & .29 & .11 & .27 \\
& & .04 & ITTF approach & .14 & .07 & .19 \\
Personalisation & .21 & .04 & ITTF approach & .14 & .06 & .23 \\
& & .04 & General education courses & -.22 & .10 & -.21 \\
\hline
\end{tabular}

Note. All multiple regression models are corrected for school effects. $R^{2}$ is the total amount of explained variance of the model, including schooleffects. $\Delta R^{2}$ is the change in $R^{2}$ after adding a particular significant independent variable to the model. If there is no independent variable significantly predicting a dependent variable, only $R^{2}$ is reported. 
Figure Captions

Figure 1. Sample item of the IPSEE-T.

Figure 2. Mean Scores and Standard Deviations of the Perceived and Desired Learning Environment. 
All students do the same work at the same moment.

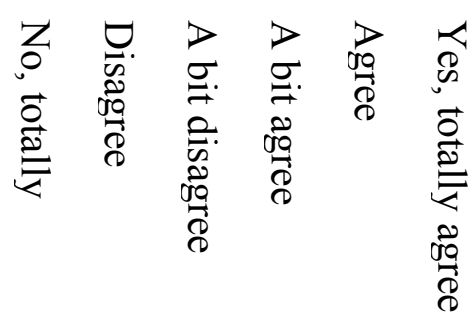

$\square \square \square \square$ a $\square$ T $\square$ happens (in the $10^{\text {th }}$ grade)

$\square \square \square \square \quad \square \square$ I $\square$ uld like this to happen 


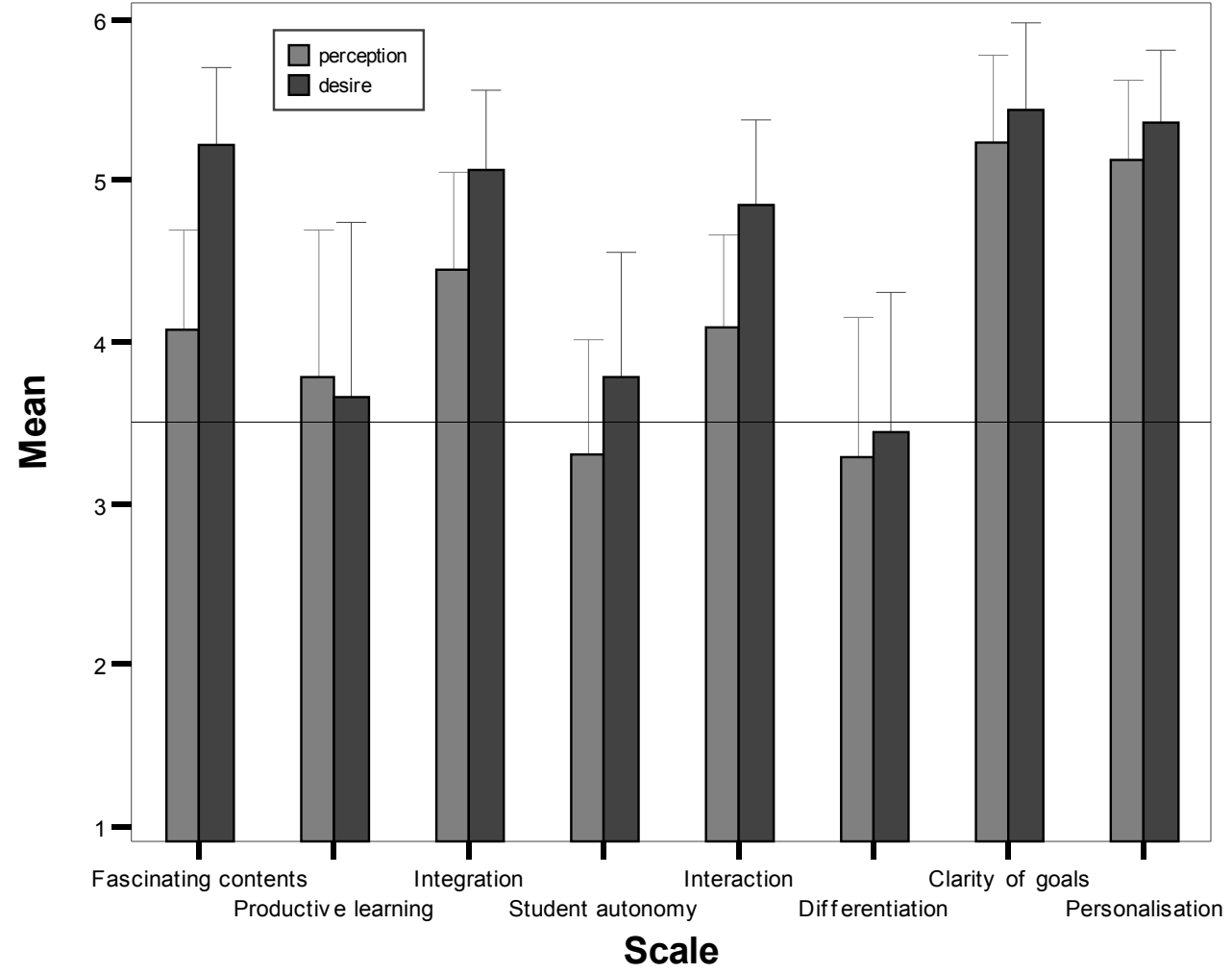

